\title{
Dmitrii Ivanovich Mendeleev and Analytical Chemistry
}

DOI: $10.1134 / \mathrm{S} 1061934810050011$

In 2009, we celebrated the 175 th anniversary of the birth of D.I. Mendeleev and 140 years to the Periodic Law. Large conferences devoted to our great chemist were held in Moscow, St. Petersburg, and Tobolsk; the anniversary was also celebrated at the conference Analytics of Russia (Agoi, Krasnodar krai). The discussions among other subjects tackled the topic "Mendeleev and Analytical Chemistry."

Mendeleev, of course, was not a professional analyst; in the 19th century in Russia, there were no professional analysts, although many chemists made significant contributions to analytical chemistry. However, Dmitrii Ivanovich Mendeleev was in close contact with this science, about which I will write below. First of all, I would like to emphasize the importance of the Periodic Law for the analytical chemistry of elements; it is clearly of great importance.

The first lecture course attended by Mendeleev at the Main Teacher's Training College, which he entered in 1850, was the course on analytical chemistry delivered by his future teacher, Professor A.A. Voskresenskii. The course was offered to students of the upper division, but Mendeleev entered the college in a year when there were no entrance examinations (these were taken biyearly). The young student had no obligatory lessons and could listen to lectures of his choice. The first scientific work of the student, as an advanced student, was devoted to the analysis and study of some silicate minerals, in particular orthite. After graduating from the College and training in Germany, Mendeleev taught analytical chemistry at several higher schools in St. Petersburg.

In the 1860s, Mendeleev edited monographs in analytical chemistry translated into Russian, in particular those by C. Gerhardt and G. Chancel [1, 2].

Afterwards, being a well-known, even famous chemist, Mendeleev encountered problems of chemical analysis, working as a forensic expert, and performing tests of the quality of product and the environment.

Mendeleev highly appreciated the importance of analytical chemistry. In his opinion, to become a chemist, one should not only learn the practice, i.e., the skills of the subject, but also three important branches of chemistry: analytical, organic, and theoretical. He believed that all these chemical disciplines were equally important and based on common grounds.

\section{REFERENCES}

1. Gerhardt, C. and Chancel, G., Précis d'analyse chimique qualitative, Paris: Victor Masson, 1855.

2. Analiticheskaya khimiya. Kolichestvennyi analiz (Analytical Chemistry: Quantitative Analysis), Mendeleev, D.I., Ed., St. Petersburg: Obshchestv. pol'za, 1866, nos. 1-3.

Yu. A. Zolotov 